\title{
The Effect of Strawberries (Fragraria $x$ ananassa) on Immediate Memory
}

\author{
Daswara Djajasasmita* \\ Department of Physiology \\ Jenderal Achmad Yani University \\ Cimahi, Indonesia \\ *daswara.dj@fk.unjani.ac.id
}

\author{
Ali Taufan \\ Department of Medicolegal \\ Jenderal Achmad Yani University \\ Cimahi, Indonesia
}

\author{
Ibnu Ananta Nugraha \\ Faculty of Medicine \\ Jenderal Achmad Yani University \\ Cimahi, Indonesia
}

\author{
Muhammad Hanif Baswedan \\ Faculty of Medicine \\ Jenderal Achmad Yani University \\ Cimahi, Indonesia
}

\begin{abstract}
Flavonoids can improve memory because they can increase blood flow in the brain, increase neurotransmitter activity and in long-term administration can ward off the neuronal damage due to oxidative stress due to their antioxidant properties. Strawberries (Fragraria $x$ ananassa) contain a wide range of phytochemicals, including flavonoids. The aim of the study is to identify and provide information on the effect of strawberries on immediate memory. This research method is an almost experimental method which is comparative, with a pretest and posttest design. The samples collected were 30 students from the Faculty of Medicine, Universitas Jenderal Achmad Yani. Sampling in this study using a single random sampling technique. Immediate memory was measured using a nonsense syllable test performed before and after consuming strawberries. Statistical analysis was conducted using the t-dependent test with $\alpha=0.05$. The results showed that the mean score after eating strawberries was 8776. This result is higher than the average score before consuming strawberries, which is 7,000 . The mean score was up 1,776. The p-value results showed a significant difference $(p<0.05)$ between immediate memory before and after consuming strawberries. On this basis, it can be concluded that consuming strawberries can enhance memory immediately.
\end{abstract}

Keywords-immediate memory, nonsense syllable test, strawberries

\section{INTRODUCTION}

In everyday life, humans cannot be separated from the process of learning and memory that is closely associated with memory. Memory is a reservoir of knowledge which is acquired to be recalled at a future time. Memory or memory is needed by humans in carrying out their daily activities, and with the increasing number of human activities today, people are increasingly required to have a better memory [1].

In general, memory is divided into three kinds, namely immediate memory that can last a few seconds to minutes, short-term memory that can last a few days to a few weeks and long-term memory that when it has been stored can be recalled for many years or a lifetime. Memory is immediately characterized by a person's memory of 7 to 10 numbers in a phone number (or 7 to 10 other obvious facts) for a few seconds to a few minutes at that point, but will only last as long as one keeps thinking about those numbers or facts. Of this division, the memory that plays a greater role in daily activities is the immediate memory, such as remembering someone's phone number, communicating (having a conversation) and others [2,3].

Immediate memory has a very small capacity, but it plays a very important part in the memory process, which is the process of stimulating human processes that comes from the environment. These small capacities for storing information represent limited processing capacities. Memory is immediately used as transient memory that can store very limited information and transform and use that information to generate a response to a stimulus [4].

A person's ability to remember has been influenced by several factors, including physiology, psychology and pathology, such as age, type of food, exercise, repeated memory exercises, ability to focus. In addition, many other factors can affect an individual's memory, including beverages, pharmaceutical supplements and substances such as flavonoids [5].

Flavonoids may improve memory in several ways, supported by their ability to interact with the molecular and physiological apparatus used in memory processing. The concentration of flavonoids and their metabolites was estimated to be in the range of 10 to $300 \mathrm{~nm}$. These concentrations were sufficiently high to be pharmacologically active on various receptors, kinases and transcription factors. The main mechanism of action of flavonoids in encephalon, namely improving peripheral blood flow and blood flow in the encephalolon (Cerebral blood flow) so that there was an 
increase in oxygen and nutrients in the encephalolon, as a result of which the learning process becomes optimal, flavonoids can also neutralize free radicals that result in inhibition of nerve cell apoptosis so that nerve cells can remain alive and differentiate [6,7].

Some research was conducted to find out the effects of flavonoids on cognitive function by using berries. In 2011, research was conducted, namely by administering blubbery juice to 9 elderly people for 12 weeks obtained the results of improved cognitive function, namely paired associate learning and word recall. In addition, in 2014 conducted research that was by giving blueberries once in 14 children aged 8-10 years obtained results, there was an increase in recall ability after 2 hours of giving the drink. There was research on strawberries conducted in a community of elderly people, namely by monitoring the foods consumed, this study was conducted for 6 years and obtained the results of people who consume strawberries more often experience a decrease in cognitive function more slowly compared to people who rarely consume strawberries [8-10].

The research showed the presence of flavonoid effects on improving cognitive function by using blueberries and also strawberries. The cultivation of strawberries in Indonesia was much more compared to blueberries however, more research using blueberries than strawberries, although strawberries also have a high content of flavonoids. Strawberries were more popular and inexpensive than blueberries. In addition to having an attractive color, strawberries also have many other benefits, USDA (United States Department of Agriculture) strawberries have a low caloric content, a source of vitamin $\mathrm{C}$, which is a powerful natural antioxidant, rich in B complex vitamins, and high levels of polyphenolic phytochemicals one of which was flavonoids. Therefore, researchers want to examine the effect of strawberry administration on memory immediately in students of the Faculty of Medicine Unjani [11,12].

\section{METHODS}

The study used quasi-experimental methods with pre-test and post-test models, comparing the memory immediately before and after consuming strawberries. The criteria for inclusion in this study are students of the Faculty of Medicine, Universitas Jenderal Achmad Yani (UNJANI) class of 2018, sleeping at least 6-8 hours in the day before the study, not doing heavy and grueling physical activity within 24 hours. The exclusion criteria were subjects taking illegal drugs, alcohol, caffeine, drugs that could affect CNS (antihistamines, diazepam, flu medications, headache medications), subjects with indigestion such as diarrhea, subjects with psychiatric problems such as anxiety and depression.

The data obtained will be examined using univariable analysis to describe the characteristics of the subjects in the study, including age. The bi-variable analysis aims to determine the immediate memory difference between before and after consuming strawberries. To test the memory difference immediately before and after consuming strawberries used $\mathrm{T}$ Dependent Test as a result of the distribution of normal data after normality test with Shapiro Wilk Test. The data was analyzed using statistical software, $95 \%$ confidence level with a $\mathrm{p}$ value of 0.05

This research has been approved by dustira Hospital Research Ethics Commission, and conducted with the subject's consent using informed consent sheet, and respects the subject's autonomy rights by keeping the subject's identity secret, and maintaining the confidentiality of research data

\section{RESULTS AND DISCUSSION}

The research was conducted in the Physiology Laboratory of the Faculty of Medicine at Universitas Jenderal Achmad Yani. That research was completed in January 2019. This study used quasi-experimental research method with 30 research subjects consisting of 15 men and 15 female students of the Faculty of Medicine, Universitas Jenderal Achmad Yani and has met the criteria of inclusion and exclusion. The data of the research results can be found in the table 1 below:

TABLE I. IDENTIFICATION OF RESEARCH TOPICS BY AGE

\begin{tabular}{|l|l|l|}
\hline \multicolumn{1}{|c|}{ Age } & Total of Participants & Percentage (\%) \\
\hline 18 & 17 & 56,7 \\
\hline 19 & 11 & 36,7 \\
\hline 20 & 2 & 6,7 \\
\hline
\end{tabular}

Based on Table 1 obtained the greatest number of subjects, namely at the age of 18 years as much as $70 \%$ and at least at the age of 20 years that was as much as $6.7 \%$.

TABLE II. DESCRIPTION OF MEMORY IMMEDIATELY BEFORE AND AFTER CONSUMING STRAWBERRIES

\begin{tabular}{|l|l|l|l|l|l|}
\hline \multicolumn{1}{|c|}{ Data } & \multicolumn{1}{c|}{ Mean } & \multicolumn{1}{c|}{ SD } & Min & Max & Median \\
\hline Before & 7,000 & 2,994 & 2 & 12 & 7 \\
\hline After & 8,766 & 2,990 & 2 & 14 & 9 \\
\hline
\end{tabular}

Table 2 shows that the mean value of the immediate memory before consuming strawberries was 7000, with a standard deviation of 2994. The lowest value obtained before strawberry consumption was 2 and the highest value was 12 at a median of 7 . The mean value after milling was 8766 , with a standard deviation of 2994. The lowest score after strawberry intake was 2 and the highest value was 14 with a median of 9 .

According to the results in Table 2, the mean value before strawberry consumption is 7000 and the mean value after strawberry consumption is 8766 . There was a mean increase in values before and after strawberry consumption in 1766 $(25.22 \%)$.

The results of immediately memory were immediately supported by scientists S. T. Francis et al. who carried out experiments on 16 female subjects between the ages of 18 and 30. Subjects were given a strawberry drink high in flavonoids for 5 days, then CBF was examined using Echoplanar MRI, obtained an increase in $\mathrm{CBF}$ at its peak of 2 hours post- 
intervention and gradually decreased after approximately 6 hours, so it can be concluded that flavonoids can increase CBF that can improve memory immediately [13].

TABLE III. DIFFERENCES OF IMMEDIATE MEMORY BEFORE AND AFTER CONSUMING STRAWBERRIES

\begin{tabular}{|l|l|l|c|c|c|}
\hline \multicolumn{1}{|c|}{ Score } & N & Mean & SD & SE & P \\
\hline Before & 30 & 7,000 & 2,994 & 0,54 & $<0,001$ \\
\cline { 1 - 5 } After & 30 & 8,766 & 2,990 & 0,54 & \\
\hline
\end{tabular}

Based on the results in Table 3 , the results of the comparison tests statistically presented before and after strawberry consumption. The mean value before strawberry consumption was 7000 and the mean value after strawberry consumption was 8766. Statistical test results using Dependent t test at a degree of trust $95 \%$ showed that there is an influence of strawberries on memory immediately in students of the Faculty of Medicine, Universitas Jenderal Achmad Yani with a significance value of $\mathrm{p}<0.001$. This means that the Zero Hypothesis (Ho) is rejected and the research hypothesis (H1) is accepted so that there is a meaningful difference in value between before strawberry consumption and after strawberry consumption, so that it can be concluded that strawberries can improve memory immediately.

The explanation for the increase in the immediate memory of the subjects was found in flavonoids which were widely contained in strawberries. Flavonoids can significantly increase $\mathrm{CBF}$ in 1 to 2 hours following ingestion with a peak time of 2 hours. This increase in CBF also increases the flow of oxygen and nutrients to the encephalon so as to improve the performance of encephalon which can ultimately improve cognitive function, one of which was immediate memory. Moreover, the increase in $\mathrm{CBF}$ can stimulate the formation of new neurons, especially in the field of the hippocampus. The antioxidant properties of flavonoids can also neutralise and inhibit the formation of SAR, so that the oxidative stress that occurs in the body was reduced. Due to the reduction of oxidative stress that occurs in the body, the least damage that occurs to nerve cells so that the performance of the encephalon will be maintained [14-16].

Moreover, the effect of flavonoids in strawberries on cognitive function was supported by long-term research by Devore et al. showed that consuming strawberries over a long time can slow the decline in a person's cognitive functions. Devore et al. asked the subjects to complete questionnaires every four years on the amount and frequency of berry use (strawberries and blueberries), lifestyle and health status. Results of subjects who consumed more strawberries showed a longer decline in cognitive function at $\mathrm{p}=0.022[10]$.

\section{CONCLUSION}

From the results of the study obtained an immediate memory picture in students before consuming strawberries has an average score of 7,000 while the picture of memory immediately in students after consuming strawberries has an average score of 8,766 . This means that there was an average increase in instant memory before and after strawberry consumption in $1766(25.22 \%)$. There was a significant relationship between strawberry consumption and immediate memory improvement to $\mathrm{p}<0.001$.

\section{REFERENCES}

[1] L. Sherwood, Human Physiology: From Cell To System. 7th Edition Canada: Nelson Education, Ltd, 2010, p. 156.

[2] A. Guyton and J. Hall, Textbook of Medical Physiology. Edisi 11 Terjemahan Irawati. Jakarta: EGC, 2008, pp. 753,760-64,767-75.

[3] R. Revlin, Short-Term Memory and Working Memory, Dalam R. Revlin, Cognition Theory and Practice. Newyork: Worth Publisher, 2011, pp. 120-121.

[4] M. Bhinnety, "Struktur Dan Proses Memori," Buletin Psikologi Fakultas Psikologi Universitas Gadjah Mada,vol. 16, no. 2, pp. 74-88, 2008.

[5] S.W. Sarwono, Psikologi Remaja. Edisi 8. Jakarta: Raja Grafindo Pustaka, 2004

[6] C. Rendeiro, J.S. Rhodes, and J.P.E. Spencer, "The mechanisms of action of flavonoids in the brain: Direct versus indirect effects,' Neurochem International, vol. 89, pp. 126-39, 2015.

[7] J.P.E. Spencer, "Flavonoids and brain health: Multipel effect underpinned by common mechanisms," Genes and Nutrition, vol. 4, no. 4, pp. 243-50, 2009.

[8] R. Krikorian, M.D. Shidler, T.A. Nash, W. Kalt, M.R. Vinqvisttymchuk, and B. Shukitt-hale, "Blueberry Supplementation Improves Memory in Older Adults," J Agric Food Chem., vol. 58, no. 7, pp. 39964000, 2010

[9] A.R. Whyte, G. Schafer, and C.M. Williams, "Cognitive effects following acute wild blueberry supplementation in 7-to10-year-old children,” Eur J Nutrition, vol. 55, no. 6, pp. 2151-62, 2016.

[10] E.E. Devore, J.H. Kang, M.M.B. Breteler, and F. Grodstein, "Dietary intakes of berries and flavonoids in relation to cognitive decline," Annals of Neurology, vol. 72, no., pp. 135-43, 2012.

[11] S. Bhagwat, D.B. Haytowitz, and J.M. Holden, USDA Database for the Flavonoid Content of Selected Foods. Prepared by. US Dep Argiculture, 2011, pp. 1-156.

[12] A. Hanif "Sebaran Stroberi (Fragaria x ananassa) di Indonesia. Seminar Nasional Pekan Inovasi Teknologi Hortikultura Nasional : Penerapan Inovasi Teknologi Hortikultura dalam Mendukung Pembangunan Hortikultura yang Berdaya Saing dan Berbasis Sumber Daya Genetik Lokal," pp. 87-95, 2015..

[13] S.T. Francis, "Cerebral blood flow response to flavonoid-rich strawberry in healthy elderly humans," pp. 433-440, 2008

[14] R. Sibarani, Perbandingan Akurasi Diagnostik antara Cognitive Performance Scale dan Mini Mental State Examination Terhadap General Practitioner Assessment of Cognition untuk Menilai Fungsi Kognitif pada Usia Lanjut. Medan: Fakultas Kedokteran Universias Sumatera Utara, 2014

[15] M. Matte, "Does Fruit Lose Nutrients in Oxidation?" 2015. [online]. Retrieved from https://www.livestrong.com/article/547675-does-fruitlose-nutrients-in-oxidation/

[16] J.P.E. Spencer, "The impact of fruit flavonoids on memory and cognition," British Journal of Nutrition, vol. 104, no. SUPPL.3, pp. 40 7, 2010 . 